\title{
THE REIFICATION OF THE WOMAN: BAUDELAIRE IN THE EYES OF WALTER BENJAMIN
}

\author{
Dario Saftich, BA \\ Rijeka (Croatia) \\ e-mail: dario.saftich@ ri.htnet.hr
}

\begin{abstract}
S u m m ary
Benjamin and Baudelaire discovered the experience of life in a modern metropolis. Walter Benjamin wrote about Baudelaire's modernity, about the mass as his main character. about the public who would read the poetry and not be able to understand it. Baudelaire embodies the democratization of poetry. Amongst new anthropological characters appears the female figure, full of contradiction. In the city, where everything has become reified, not even the woman can avoid this fate. Thus, without regard to Walter Benjamin's optimism, it is impossible to find salvation in love for woman and art. Beatrice no longer lives here. Baudelaire was the first to realize that the bourgeoisie was ready to strip the poet of his social role which he had enjoyed although it was forced upon him - since he has experience regarding the true nature of merchandise - to recognize the market as an objective circumstance. Therefore, the theory of the demise of aesthetic art, as one of the obsolescense of specific art forms, can be almost paradigmatically shown in Baudelaire's lyricism.
\end{abstract}

Keywords: metropolis, democratization, woman, poetry, art, reification, bourgeoisie, market

\section{Introduction}

Benjamin and Baudelaire discovered each in their own way, the experience of life in a modern metropolis, the one that is both alienating and stimulating. Walter Benjamin wrote of Baudelaire's modernity, of the masses that served as his main heroine, the public that would read his poetry all the while not being able to understand it. Benjamin differentiates between the concept of experience and the concept of lived experience: the latter allows for rational perception of life's shocks, their reflection, which thus allows us to defend our consciousness from their further permeation. Simple experience is that which stems directly from shock, lacking reflection: this is the case with Baudelaire who, within urban life, constantly suffers shocks which are a result of the masses spontaneous passing, the effects of light, the novelty of products and other situations typical of life in a modern metropolis. The mass would then be the secret character of Baudelaire's poetry; although it is never fully presented, it is nonetheless obsessively present within his work. We needn't search for it within the poetry's content 
or theme, but in the poetic form, the nervous rhythm of Baudelaire's verse. Baudelaire was the first to realize that the bourgeoisie was ready to strip the poet of the social role he had enjoyed up until then. It was because of this that Baudelaire assumed the role of seeking out the poet's dignity in a society that was devoid of room for dignity of any sort.

Baudelaire was obliged - as he had experience in regards to the true nature of goods - to recognize the market as an objective circumstance. Because of this, through his mask, he presented the reification of art in a grotesque manner. A woman could not avoid reification in such a social context. The poet attempts to find salvation within the love for a woman, the ideal of beauty and art. But the attempt is in vain. In Baudelaire's case, Dante's Beatrice necessarily assumes different contours. It is surely not accidental that the main symbol, the incarnation of modern urban landscapes, one appearing as an allegory within Baudelaire's poetry, is a prostitute.

\section{The Demise of Estethic art}

The theory of esthetic art's demise, as a theory of the obsolescence of specific art forms, can be almost paradigmatically depicted in Baudelaire's lyricism, claims Danko Grlic. As such, Benjamin is convinced that The Flowers of Evil are the last lyrical collection to have made a crucial influence on the European spiritual situation.

Somewhat paradoxically, however, the book which became a classic throughout the decades did not count on its receiving favor from readers, an expectation which was fulfilled in the beginning, because the conditions for acceptance of lyricism were unfavorable. It was as if Baudelaire kept in mind a public which found reading lyricism difficult, and he announced this reality belonging to him and the readers both in the very introduction, an un-lyrical reality of stench, nastiness and hell:

It is the Devil who shall lead us hence!

Repugnant objects meet us on the way

More close to Hell with each passing day

We walk unhorrified, despite the stench

We are no longer free subjects in the creation of our own atmosphere, highlights Danko Grlic, some «living demon» controls the threads of our destiny, which itself leads to loss of things, i.e. the impossibility of deliberate recollection. On this path to hell, we have lost the possibility of distancing, we are no longer sensitive, poetic sensibility disappears, and so every pure, honest desire of the poet is today pointless. Yet Baudelaire still writes about it, still smells that stench, which indicated that he has not yet numbed fully, he still knows he is heading to hell and feels how that stench is no longer repulsive to neither him nor his readers.

Baudelaire's lyricism announces the general problematizing of lyricism as a form of expression, more so, it can be shown within the lyricism that, historically, the constitutive and receptive conditions for lyricism have already demised. 
And while epic eloquence has proven impossible, partially because information has become the basic principle of interhuman understanding in an individualized and atomized civil society, Baudelaire's lyricism displays a paradigmatic, anthropological reversal in the manner of people's survival within advanced capitalism: in it, people's experience is barely possible if not as shock reception.

This lyricism is therefore an indicator of such experience, in which loss of experience is actually registered. Because that stage of development is where the social aspect of man's existence was educated, where only unusual and extreme experiences are allowed which could still possibly show to be suitable for lyricism.

In that aspect, loss of experience overlapping with loss of tradition for Benjamin foremost has a historical index. Through capitalistic application of technical achievement, the worker becomes an additive to the machine; his work activity becomes such as to disable experience.

And so Baudelaire introduced experience in terms of shock as the heart of his artistic endeavor. More so, it was he who learned to parry the blows, enabling existence for himself and others despite the earthquake cancelling out that possibility. Thus, Benjamin arrived at the conclusion of the people's loss of experience in a highly developed society as well as the substitution of that lost experience by shock reception.

In modern society, in other words, the increasing number of blows in place of individual defense mechanisms, there has raised a series of mechanical replacements that, although they shield us partially, also strip us of the possibility to understand and assimilate that which is really happening. In that sense, media also acts as an anesthetic against the blow of novelty, Grlic writes: If shock can be accepted, experience will occur after all. However, as consciousness is mostly preoccupied with defending against the blow, repulsion of stress, experience related material is suppressed into the unconsciousness. Experiences lived through allow us to rationally elaborate life's shocks and defend our consciousness from their attack and deeper permeation. In that sense, experience is simply the immediate result of shock, lacking any medium: this is the case of Baudelaire who repeatedly experiences blows caused by the passing masses, the lights of the metropolis and other situations typical for the life of a modern city. The philosophical and esthetic value of Baudelaire's poetry lays the fact that he elevated the experience of shock reception to an esthetic principle.

The concept of experience, as the reception of a blow, notes Grlic, is what Benjamin tried to render plausible through one of Freud's hypotheses: consciousness' primary function is not accepting stimuli, but attaining protection from stimuli. Accepting Freud's differentiation between unconscious memory and the conscious act of recollecting, Benjamin, as interpreted by Baudelaire, bestows a special place to the thesis that full consciousness and abandoning traces of memory are abhorrent, as well as the claim that consciousness' primary function is the organism's defense against blows, shocks from the external surroundings. It is then, when the consciousness is no longer able to process the shock, the creation of traumatic symbols arises. And what saves man within modern society, as we have witnessed, is a continuation of the series of mechanic substitutes which protect us, even if only partially. 
Therefore, according to Freud, terror occurs when the consciousness can no longer find its function of protection: an earthquake which cannot be evaded causes terror. Baudelaire offers impressive images which can be explained with the help of Freud's hypothesis. He often speaks of the ghost within which is the artist, before he is beaten, consumed with terror. Grlic claims that Benjamin interprets this duel of Baudelaire's as a vestibule to artistic creation itself: It is simultaneously a type of experience, which assumes creation and acceptance of lyricism, present in Baudelaire only as a relic. If the reception of the blow has become a norm of experience, this occurrence clearly indicates expiration of the overall esthetic experience. Shock, however, as an esthetic principle, doesn't allow poetic objects to be experienced in their own and original quality, but as something foreign, strange, nauseating, selfdestructive.

Therefore, Baudelaire represents the social type of wanderer, the flaneur, the one familiar with shock reception within an everyday way of life. The wanderer lives in a large city, within the masses that ceaselessly hurry past; all the constant shoving, running, and racing of the masses acts as a shock. However, partly because of his own insecure social standing, the working class' manner of existence, one in which production is dependent on the goods market, is not foreign to him. Although, since he is not yet fully integrated into this manner of production, the wanderer protests through his fashion of existing against the very manner of production and its consequences on the market. The wanderer's art is interrupted by the type of artist, one recognized in early civil tradition, one who was relatively independent in his social position, at least in comparison to the disasters of economic and market fluctuations. Even former protection of patronage, one on the verge of extinction, is subject to the laws of market and capital. According to Benjamin's theory, this is an important paradox of Baudelaire's poetry, it wishes to be independent and self-sufficient, but the artist is increasingly forced to find a buyer for his goods. Esthetically, this implies the artist's realization that one historical figure in art has worn out. It is just this that leads to new esthetic values, a conversion in the very nature of artistic works, works that shall be more successful and valuable the more they thrive in the market relations and goods area.

\section{The new Anthropological Characters}

In his essay on Paris as the capital of the nineteenth century, Benjanim, in addition to flaneurs, speaks of other psycho-anthropological characters such as dandy and prostitutes, and parses the new character of production and the flow of merchandise. A situation in which the civil classes are faced with retracting their previous contract with a relatively independent poet inevitably leads to a need for that poet's prostitution, i.e. the reification of art.

The central symbol, the incarnation of that magical landscape, which emerges as an allegory in Baudelaire's poetry, is the prostitute. Through this figure Benjamin proves that the female body has lost its aura of natural femininity and become 
merchandise, consisting of dead and jaded fragments. Its beauty has become a type of cosmetic disguise (make-up and fashion).

The prostitute, as Walter Benjamin notices, is the only merchant who, along with his merchandise, also sells himself. Today, this privilege might be lost, writes Sead Alic: That which once determined prostitution, has become a constituent of the modern world. Man breeds a prostitute within himself in order to claim a place within the social division of labor which realistically, belongs to him already.

In his work My Heart Laid Bare, Baudelaire himself writes that there exists in every man at every moment two simultaneous postulations, one toward God, the other toward Satan. Beckoning God, or spirituality, is the desire for ascension, beckoning Satan, is the pleasure of descent.

Even in the poet's love toward the three most important women in his life, the ones who inspired many poems in The Flowers of Evil, emphasizes Visnja Machiedo, there surfaces that insurmountable contradiction, that desperate duality which can only be overcome by the magical beauty of the poet. His long, tumultuous affair with the sensual, cruel and unrefined mulatto woman Jeanne Duval («Black Venus») undoubtedly belongs to the "pleasure of descent», the seeking out of urge-driven, bodily delights, indulging in vices, which at the same time form some type of self-punishment.

The desire for ascension, pure love, is manifested in the platonic affections for Mrs. Apollonie Sabatier. It reads as an almost medieval, knight-like ideal of love toward an unattainable maiden. As soon as the opportunity arose for this enlightened ideal to be realized in its full capacity, the long present desire in the poet's heart dwindled.

Baudelaire is not Dante, times had changed irreversibly. In place of the Middle Ages where certain ideals still lingered, if anything the ideal of enlightened art, by the mid nineteenth century we arrive in an entirely different atmosphere in which all becomes reified. Baudelaire's «Beatrice» does not lead him toward the Empire; the poet is tormented by his ambivalence between adoration and hatred for women. And so the sublime Beatrice is transfigured into a demon-like caricature of Dante's heavenly maiden.

\section{Fetishized Femininity}

In the scent of a woman, the smell of her hair and her breasts, the poet searches for an inspiration that will bring him close to great eras of eternity. And memory dazes the consciousness in regards to time's quick passing. The melancholy observes with horror as the earth returns to its nude natural state, one no longer surrounded by an tinges of history, no aura.

Within this frame we can also view Angela Carter's novel Love. Love builds upon Baudelaire's previous example (as well as surrealism, another of Benjamin's important models) of introducing fetishized femininity as a symbol in itself and a 
substitution for the social-historical crisis, in terms of figurative speech and a narrational perspective.

According to Angela Carter's own admission, the entire novel along with the main character's tragic end, can be read as a sort of allegory: it is all representative of a global, social and cultural situation, a time (especially the sixties of the twentieth century) in which utopias were forcefully met with the reality the world changing as an impossibility. Simply, youthful utopias must end. And so Angela Carter's work touches upon the problem that is the reification of women and society in general. Ultimately, parallels can be drawn between the two forms of fetishism and reification, i.e. those according to Marx and those to Freud's theory. In Freud's opinion, the body is the well of fetishism, while according to Marx, reification affects the laborers' work and its value. The two aspects are both very present in reified culture. The same fate of reification has struck both art and the artist. The art in question is one which has, as Benjamin clearly determined, been completely changed in relation to historical experiences and finds itself in the windswept midst of market and goods oriented relations. The first to clearly indicate this crisis was Baudelaire. And so we return to the story's beginning.

\section{The aura's disintegration}

For Baudelaire, the most tragic experience was that the disintegration of aura, something he strongly sensed, incorporated itself into and affected his own lyricism. It was because of this that he considered the haloed poet to be hopelessly aged, although he himself felt lost in the world of the masses. Still, he didn't surrender. The very title, Flowers of Evil contains the essence of Baudelaire's poetics, notes Visnja Machiedo: To extract the beauty from the hideousness of life and the misery of human existence, to discover the flash of eternal beauty in the trite passing of the everyday. It is just this, the binding of beauty to misery, along with the explosiveness of poetic verse, bridled with classic prosody, in light of upcoming liberation even from traditional poetic forms, that make Baudelaire's poetry - in which some stylistic elements of the medieval, Renaissance, mannerism and Baroque are interwoven in an entirely new fashionextremely modernistic.

In Baudelaire's opinion, a novel cult value, one wishing to salvage its independence, may appear disguised in beauty. That, which is so attractive in enjoyment of beauty, is an image of a time past. Art pulls beauty from the depths of time. This no longer occurs in technical reproduction. Not one new single character of art emerges with the technical possibilities of art, but rather the general demise of art. Benjamin claims that photography accomplishes forms that don't stand independently in relation to society, but have rather become its integral identity. This is why Baudelaire speaks of the dangers of photography and how the stupidity of the masses aids in its progression. 


\section{An Attempt at Salvation Through the Love for a Woman}

If we observe Benjamin's interpretation of Baudelaire's Agreement, we will see that to him, agreement constitutes a traditional experience which, wishing to insure itself from crisis, escapes into the cult domain, i.e. beauty as a cult value in art. Namely, the fact that recovered time can be found in art, thus found in something so hermetically cultic, cultically colored.... beauty, a beautifully shaped impression - that was comprehensible to Benjamin as an attempt, but unacceptable as an intention.

That which makes days of festivity so great, says Benjamin in his interpretation of Baudelaire, is an encounter with early life: In this thesis, beside the dimension of mystique tied to interpretation of Baudelaire's "A Previous Life», there is also present a Proustian thesis about the ceremoniality of spirit which considers itself above time. Namely, in this moment in which the spirit enters the horizon of one of its previous states, in which spirit remembers it - the punctuality of time is negated, time itself is negated. Here, Proust remains eternally restorative. Into Baudelaire's experience, however, as Benjamin stated, the spleen has managed infiltration.

The spleen appeals entrance to objective time into the war against memory, writes Alic: Benjamin's analysis of Baudelaire breaks down, in one possible sense, the «humanity» of time. At the level of experience, scent, memory and beauty are reflected. That which is human is, therefore, the temporalization of man. Scent, in which two aspects of time reconcile, the past and the future, as that which is human in time, therefore represents the modus of man's temporalization. Beckoning the past into the present, making realizations of that which has seemingly been left only in traces vivid, collection of scent, touch, glance, is to Benjamin an attempt at «filling life with the greatest of sobriety».

In Baudelaire's verse «Spring, the Beloved, has lost its scent» Benjamin spots a discrete confession regarding of the breakage of experience. That constitutive, traditional experience is broken within itself under the flurries of technology. That which is temporalin man is no longer gathered in scent, because scent, as something immanent, has given upon itself. If Spring has lost its scent, that only means that man is lost to scent as a gathering moment in which that which has past and that which is yet to come can reconcile/be gathered. Let us read into it this way: can a man who has today died for the scent of a certain spring ever be reborn, i.e. be born, gathered in a moment in which the past and future give birth to youth.

Nonetheless, emphasizes Visnja Machiedo, the poet tries to find salvation from upsetting melancholy, dispiritedness and languish of spleen in love toward a woman, in the ideals of beauty and art and ultimately, in consciousness. However, the poet will also seek salvation in a Dionysian comsumption of wine, art and erotica. The antfarm that is the metropolis will not allow for more enlightened ideals. 


\section{Conclusion}

Baudelaire's poetry, living the experience of the blow, divides manner of survival with the masses in civil society. By the materialistic understanding, the masses' existance is primarily determined by the situation of the working class in the productional process itself. That very process, however, barely still allows for experience in a strict sense. Baudelaire's lyricism can, therefore, be marked as an immenent contradiction: it wishes to express poetry, an endevour which would entail experience, which, in order to be even be, must be within geniune modern materialistic production. Hence his lyricism sensibly, albeit nervously, almost hysterically, reacts to a certain situation in which poetic experience can no longer be viewed as an unconditional allowance. Baudelaire wishes, according to Benjamin's words, to express this paradoxal situation in order to enable, find and offer, even by means of expiration of esthetic experience, a social and immenent esthetic place to art, which has become in itself utterly problematic, and above all questionable.

Benjamin attempted to determine all that which is artistic in Baudelaire firstly through sociological categories. In that sociological context, he marked Baudelaire as a poet completely in the midst of shock reception, specifically because his life, as emphatically personal and seemingly isolated as it was, took place amongst the masses.

Baudelaire's poetry marks the price at which modern feeling is attained: desolation of the aura within the experience of shock. Consent with that desolation, writes Benjamin, cost the poet dearly. But that is the law of his poetry. Still, Benjamin remains an optimist: he greets the new age and the gradual but guaranteed disappearence of aura-esque art.

With Baudelaire, we see the democratization of poetry at work, not only because of the abandonment of default forms of bound verse. In the midst of new anthropological characters, there appears the woman, full of contrast. The central symbol of this novel democraticized femininity, which reads as an allegory in Baudelaire's poetry, is the prostitute. Within the metropolis, within a society where everything has become reified, not even a woman can escape this fate. That means, disregarding Water Benjamin's optimism, that it is impossible to find salvation in love for a woman and art. Beatrice no longer lives here. But poetry remains alive. Through transformation of Dante's maiden into her antithesis, we have attained an art subject and allowed by newly created circumstances. The French poet succeeded, after all, in creating an art in which the losers are victorious, pushed to the margins of modern civilization. Wonder and beauty are unveiled even within the ugliest aspects of occurence. The enlightened idea which Baudelaire looked for in The Flowers of Evil is an unsightly broad or a hysterical, monstrous slut. In place of the revered Beatrice, we have the «realistic». 


\title{
Bibliography
}

Alic, S. (2003), The Birth of Tragedy. Cakovec: Phenomena

Baudelaire, C. (1994), The Flowers of Evil, Spleen of Paris. Zagreb: Sys Print

Gjurgjan, I. L. Textbook.

Grlic, D. (1984), The Thoughtful Adventure of Walter Benjamin. Zagreb: Globus

Metodički obzori 9; vol. 5(2010)1

Pregeldni rad

UDK: 82.09

Primljeno: 20. 11. 2009.

\section{REIFIKACIJA ŽENE: BAUDELAIRE U OČIMA WALTERA BENJAMINA}

\author{
Dario Saftich, prof. \\ Rijeka (Hrvatska) \\ e-mail: dario.saftich@ri.htnet.hr
}

\begin{abstract}
Sažetak
Benjamin i Baudelaire otkrili su iskustvo života u modernoj metropoli. Walter Benjamin je pisao o Baudelaireovoj suvremenosti, o masi koja je njegov glavni junak, o publici koja će čitati poeziju i neće je biti u stanju razumjeti. Kod Baudelairea na djelu je demokratizacija pjesništva. U sklopu novih antropoloških likova pojavljuje se lik žene, pun kontrasta. U velegradu, u društvu gdje je sve postalo reificirano, ni žena ne može izbjeći tu sudbinu. To znači, da bez obzira na optimizam Waltera Benjamina, nemoguće je naći spas u ljubavi prema ženi i umjetnosti. Beatrice više ne stanuje tu. Baudelaire je bio prvi koji je shvatio da je buržoazija već bila spremna oduzeti pjesniku socijalnu ulogu koju je do tada uživao i bio je moran - jer je imao iskustva što se tiče prave prirode robe - priznati tržište kao objektivnu okolnost. Dakle Teorija kraja estetskih umjetnosti, kao teorija zastarijevanja pojedinih umjetničkih formi, može se gotovo paradigmatički prikazati u baudelaireovoj lirici.
\end{abstract}

Ključne riječi: metropola, demokratizacija, žena, poezija, umjetnost, reifikacija, buržoazija, tržište 